\title{
Expectations and Christian Perspectives Regarding the Future
}

\author{
Ioan-Gheorghe Rotaru
}

\begin{abstract}
Christianity regards the future in the sense that the future events will have the vocation of eradicating the evil for good, ending the fight between good and bad and eliminating the source of evil once and for all. In this study ${ }^{1}$, looking from this Christian perspective regarding the future, a person who embraces the Christian values, no matter the present difficulties, will go further with stoicism and with faith, convinced that future will bring the complete solution to everything. Regarding the knowledge, a Christian considers that during his lifetime he knows the things only partially, but, along with the coming of Jesus Christ, he could reach the full understanding of things, fact which will determine him to move on in life facing any vicissitude with faith, waiting for the accomplishment of all the divine promises.

KEY WORDS: Christian perspective, problems, provocations, expectations.
\end{abstract}

\section{A Christian Perspective on the Way of Approaching the Present or Future Life Problems}

\begin{abstract}
$\Delta$ uthentic Christianity is not an approach of the temporal - existence and of its elements, but instead, it is the understanding of the stagnant things of God, starting from the unstable ones from the earth. The beautiful Christianity is not the annihilation of the temporal life from earth in favor of the one from the sky, but it is the
\end{abstract}


exemplification through the passing life, that there is an eternal life which we should appreciate more, doing a lesson from it. ${ }^{2}$

When everything becomes uneasy and it is on the rack of the sea of our life, foamed sea and often flagellated by the numerous winds of temptation and sin, when the ship of our life is being hit and ready to sink, when we are veiled by the black night of the lack of faith, when we are dealing with the instability of our working place or with financial crisis, when we have family or health problems, when around us we hear only cries for help, in different instances, we would have to say, each of us, "Where could my help come from?" It is not easy to be alone, to face every challenge, to come to be exhausted, without powers and resources, to cry loud and not be heard, and after you have tried and finished all the means and the resources of your competencies, to be able to ask yourself and to call out through faith exclusively: "Where could my help come from?"

When you fought and struggled, when you didn't find an escape, and when you didn't know where the escape is, where the solution to all your problems is, then call out for God, Your Creator, and believe with all your heart that the help will definitely come from Him, and only from Him. It is not God's will for His sons to be taken down by the burden of the life's concerns. ${ }^{3}$ What is mother's sweet word for her child and what is the child's word for his mother, what is the path for the lost being, what is light for the one who walks on dark during night and throughout dangerous places, that is God's intervention for the faithful human being, who has faith in God and comes with faith with any problem, regardless of its nature, to Him, acknowledging his sins and wanting to receive the divine liberation and support in the expressed needs.

The Christian's life has sense and value only if it is an important preoccupation for his own redemption, and the real acquisition of this by real commitment with Jesus Christ the Savior. In this way the Christian's life on earth is not manifested like a simple biological existence, but as a spiritual experience specific to human beings, with finality about his quality of spiritual being in the body, possessing reason, sensibility and free will, creativity and carrying material and spiritual values. ${ }^{4}$ 
A Christian will always be aware, both in the present and in the future too, by the fact that God is ready to listen to our problems, and intervene for us as humans with His help. The problems the human being is dealing with in the present, but which will carry on in the future too, are found in all the parts of our life. In this way, for the present and for the future too, there are still problems from the family life, from social and economic life, or from other domains, problems which we search and will search solutions for. For an authentic Christian neither the present nor the future will carry on the concern for him, because he tackles the problems through faith and with full trust in his Creator. For such a human being, the present and the future won't be sources of anxiety. Even though he doesn't know the future, a believer puts his life with all the problems in the hand of The One that has the restrains of all there is on earth. We list some of the present and future issues, challenges in which the human being expects help from The One that has all the power:

\section{Problems and Expectations in Family Life}

The Creator said even from the beginning that "it is not good for the human being to be alone, to do a proper help for him" (Genesis 2,18). In the Paradise Garden, Adam, the human created by God, above all, the inferior beings, had everything he needed on hand. He had at discretion all sorts of aromatic and ripened fruits; he enjoyed all the natural beauties of the garden and breathes the wonderful smell of flowers. All types of animals that were playing in front of him and the abundance of birds which sang wonderfully in the garden's trees, kept the boring away from Adam. Besides all these, the celestial emissaries, God's angels and even God the Father, came daily to visit, offering to the new created human being, that atmosphere of a wonderful collective, superb, of an apart and special relationship. ${ }^{5}$ Beside all these, did he need something else? The Creator tells Adam that he will give him a proper help. "And God said: 'It is not good for human being to be alone; let's create him a proper help.'"' The human being was not created by God to live in loneliness, but he has to be a sociable being, that is why God decided to create for him a life partner 
similar to his nature. This fact should determine the married ones, and especially the men, not to forget that their life partners, their wives, were given to them by God to be their help. God made us to be the help of one another, but today, in the conditions of sin, we can become not only helpers, but obstacles for the others.

There are today couples who do not love each other anymore, who don't have a relationship, who only talk the daily problems, because they have lost the daily communion with God, through praying and the study of the Holy Book. They cannot find time for all these and for discussing one with another, from heart to heart. But God's prophesy was that the Elijah of our times will turn the heart of the parents towards children and the children's heart towards their parents. ${ }^{7}$ Here there is the key to solving the family problems. ${ }^{8}$ Even though obstacles, troubles, and demoralizations can come on the way, the wife should not bear the thought that their union is a mistake or a disappointment. Make the decision of being everything it is possible to be one for each other. Continue with the first intentions. Embrace in each possible way in order to fight against the battles of life. Take time to search how you could broaden the other's happiness. Be indulgent with the other. Then marriage, instead of being the end of love, will be only a weak start of it. The warmth of the real friendship, love which bonds heart with heart, is a pre-tasting of the sky's joys." ${ }^{\prime \prime}$

Nowadays there is a prophesy that in the near future there is a necessity of reformation and pre-figuration through the work of the Prophet Elijah, in order to light or keep the sacred fire in the family, an institution created and blessed by the Creator. On this aspect there are eloquent the advice of an American writer:

Parents Should Give Children Right Direction-With us as parents and as Christians it rests to give our children right direction. They are to be carefully, wisely, tenderly guided into paths of Christ-like ministry. We are under sacred covenant with God to rear our children for His service. To surround them with such influences as shall lead them to choose a life of service, and to give them the training needed, is our first duty. Children May Be Daniels and Esthers Today-God's purpose for 
the children growing up beside our hearths is wider, deeper, and higher, than our restricted vision has comprehended. From the humblest lot those whom He has seen faithful have in time past been called to witness for Him in the world's highest places. And many a lad of today, growing up as did Daniel in his Judean home, studying God's word and His works, and learning the lessons of faithful service, will yet stand in legislative assemblies, in halls of justice, or in royal courts as a witness for the King of kings. Multitudes will be called to a wider ministry. The whole world is opening to the gospel. ... From every quarter of this world of ours comes the cry of sin-stricken hearts for knowledge of the God of love.... It rests with us who have received the knowledge, with our children to whom we may impart it, to answer their cry. To every household and every school, to every parent, teacher, and child upon whom has shone the light of the gospel, comes at this crisis the question put to Esther the queen at that momentous crisis in Israel's history, "Who knows whether thou art come to the kingdom for such a time as this?"10

\section{Economical Problems}

The Holy Scripture describes the fact that Israel's children carried on many troubles because of the slavery from Egypt, and called out to God calls of despair: "And it came to pass in process of time, that the king of Egypt died: and the children of Israel sighed by reason of the bondage, and they cried, and their cry came up unto God by reason of the bondage. And God heard their groaning, and God remembered his covenant with Abraham, with Isaac, and with Jacob. And God looked upon the children of Israel, and God had respect unto them."11 If you have today, or you will have in the future problems connected with earning your every day bread, if you fill a burden from the everyday concerns and those of tomorrow, call out to God for liberation. The present and the future too will bring, day by day, problems related to the working place, problems about their instability, about some material lacks, about searching for a working place, or a better paid working place, and in all these situations a Christian will turn with faith towards his God, in order to ask for support, because he promises us bread: "I have been young, and 
now am old; yet have I not seen the righteous forsaken, nor his seed begging bread. "12

\section{Moral Problems}

From the fall of the first human family into sin, and until the end of the history of the mankind sin, we will continuously come to face moral problems. On the time of the Israel people, we find out that God showed the fact that He was close to them and that he only wanted what was good for them, being ready to offer them forgiveness for those breaking the Laws. In the Sanctuary from the wilderness and ulterior in the Temple there was the monstrance ${ }^{13}$ which was covered with a lid, called the expiation lid or the throne of mercy, where god was revealed to them:

And thou shall put into the ark the testimony which I shall give thee. And thou shalt make a mercy seat of pure gold: two cubits and a half shall be the length thereof, and a cubit and a half the breadth thereof. And thou shall make two cherubims of gold, of beaten work shall thou make them, in the two ends of the mercy seat. And make one cherub on the one end, and the other cherub on the other end: even of the mercy seat shall ye make the cherubims on the two ends thereof. And the cherubims shall stretch forth their wings on high, covering the mercy seat with their wings, and their faces shall look one to another; toward the mercy seat shall the faces of the cherubims be. And thou shall put the mercy seat above upon the ark; and in the ark thou shall put the testimony that I shall give thee. And there I will meet with thee, and I will commune with thee from above the mercy seat, from between the two cherubims which are upon the ark of the testimony, of all things which I will give thee in commandment unto the children of Israel. ${ }^{14}$

The same were the precious stones Urim and Thummim, from the breastplate of the Great Priest, which had the role of showing the God's will, in the things brought in front of him. (Exodus 28: 30). Throughout these stones God's will is shown, when there were brought in front of Him some reasons. In the situation in which there was a shade of light on the stone from the right side, it meant 
that God approved the thing they have asked for, and when there was a shade of light on the stone from the left side it meant God's disapproval. All these shown the God's help or answer, help or answer that the people received from God, when it called out to Him. In this way, throughout all the sacred ceremonies from the Sanctuary and later on from the Temple, which took its place, the people was thought the great lessons and truths about serving Jesus Christ, but once a year, everyone's mind was focused on the closing events of the earth's history, and of the great battle between Christ and Evil, and in the end the abolishment of sin and of the sinners from our world. ${ }^{15}$ God the Creator is ready today and tomorrow to answer to your needs.

Saint Basil the Great states that the evil's temptation is not a fatality, even though through it came the human falling. God gives us power to fight against it, following His commandments. If the falling was possible, repairing the mistake is possible too, by following the circle initiated by God, which can lead us to crowning. ${ }^{16}$

Problems and Challenges from Different Domains of Life

For all these, for the present as well as for the future, God is a help which never misses in needs: "God is our refuge and strength, a very present help in trouble." (Psalms 46:1) If today or in the future the human is burdened and feels as a slave of some vices that he cannot get rid off by himself, in other words he is a slave of sin, he can bring his spiritual burdens before God through holly praying, asking for relief and liberation from these. The Christian belief is and has to stay one of hope, joy, love, forgiveness and triumph of good over evil, and the church has to be the carrier of these virtues. 17 The Saint Cyril of Alexandria said that when you truly feel God working in you, you are not feeling selfishness, nor a selfish interest hidden in yourself, nor a temptation of an ugly sin. You feel all these as being burnt by His presence. ${ }^{18}$

\section{God's Protection Gives Safety for the Future}

The Christian life is not without dangers. These are even greater in a time of peace and calm, then in a time of persecution. In the Christian life there isn't a neutral area. In any feeling, in any thought, 
in any decision or movement, the Christian is a hero or a coward. ${ }^{19}$ The fact that God is the help and the support of the human being, gives him the moral and spiritual strength of dealing with life's problems without fear:

God is our refuge and strength, a very present help in trouble. Therefore will not we fear, though the earth be removed, and though the mountains be carried into the midst of the sea; Though the waters thereof roar and be troubled, though the mountains shake with the swelling thereof. Selah. There is a river, the streams whereof shall make glad the city of God, the holy place of the tabernacles of the most High. God is in the midst of her; she shall not be moved: God shall help her, and that right early. The heathen raged, the kingdoms were moved: he uttered his voice, the earth melted. The LORD of hosts is with us; the God of Jacob is our refuge. Selah. Come, behold the works of the LORD, what desolations he hath made in the earth. ${ }^{20}$

God's antidote for all the dangers that humans are threaten by, both inside and outside, is His secular call, which should wake him up at a state of awareness and praying: "Therefore thus said the LORD, If thou return, then will I bring thee again, and thou shall stand before me: and if thou take forth the precious from the vile, thou shall be as my mouth: let them return unto thee; but return not thou unto them. And I will make thee unto this people a fenced brasen wall: and they shall fight against thee, but they shall not prevail against thee: for I am with thee to save thee and to deliver thee, said the LORD. And I will deliver thee out of the hand of the wicked, and I will redeem thee out of the hand of the terrible." 21

The Holy Scripture presents God as being our Helper in any moment and in any situation: "Our help is in the name of the LORD, who made heaven and earth. ${ }^{22}$ The human heart which has faith in His Creator will get help: "The LORD is my strength and my shield; my heart trusted in him, and I am helped: therefore my heart greatly rejoices; and with my song will I praise him. The LORD is their strength,

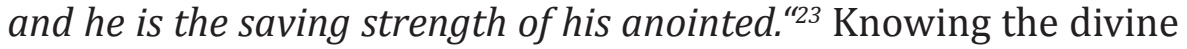
character helps you in all the future challenges because God is ready 
to take your hand and offer his support: "The steps of a good man are ordered by the LORD: and he delighted in his way. Though he fall, he shall not be utterly cast down: for the LORD uphold him with his hand. I have been young, and now am old; yet have I not seen the righteous forsaken, nor his seed begging bread."24 The call of the mournful makes the heart of The Almighty and Merciful God to vibrate even more. ${ }^{25}$ As a human, be ready all the time to be taken by the Hand of The Almighty and always be shown the way by His Hand.

From the moving of stars throughout space and up to the smallest particle, all the things from nature follow the Creator's will. God is the One that takes care of everything and sustains everything it is created by Him. The God who supports the unlimited worlds in the space immensity, guards in the same time the needs of the bird that sings without fear its modest song. In many situations, when people start their tiring daily work, or when they bow in praying, when they go to sleep in the evening, or when they wake up in the morning, or when the rich parties in his palace, or when the poor gathers his children around the poor table, all are in the guarding attention of God. There is no tear on earth without God knowing about it, and there is no joy or laugh He hadn't seen. If we, as people, would fully believe all these facts, then all our unfunded concerns would disappear and then our life would not be full of disappointments as it is now; because each and every thing, big or small, would be place in God's hands, Who is not troubled by the multitude of the concerns nor overwhelmed by their weight. We would enjoy an interior peace which many didn't have the chance to know. ${ }^{26}$

\section{The Divine Expectations of the Human Being Fallen into Sin}

\section{Recognition of Evil Deeds and Willingness to Change}

"The joy of our heart is ceased; our dance is turned into mourning. The crown is fallen from our head: woe unto us that we have sinned! For this our heart is faint; for these things our eyes are dim. Because of the mountain of Zion, which is desolate, the foxes walk upon it. Thou, O LORD, remain forever; thy throne from generation to generation. Wherefore dost thou forget us for ever, 
and forsake us so long time? Turn thou us unto thee, O LORD, and we shall be turned; renew our days as of old. But thou hast utterly rejected us; thou art very wroth against us. ${ }^{27}$

God's love for man, love of man for God and for others, which is lighted and nourished in the Christian heart by the divine grace, has the power to detach man from the pleasures, interests and desires of the flesh, and has the power to call him, to exhort him and even to push him to heroic actions, deciding him easily to confront enthusiastically, any distress and suffering. ${ }^{28}$ Given the fact that temptation is always present and installed in our own home, it is necessary that Christian watchfulness or vigilance never to be ceased or weakened. ${ }^{29}$

\section{Sincerity and Regret for the Sins}

To feel sorry for our sins, tearing our hearts, as the holly Scripture said: "And rend your heart, and not your garments, and turn unto the LORD your God: for he is gracious and merciful, slow to anger, and of great kindness, and repented him of the evil. Who knows if he will return and repent, and leave a blessing behind him; even a meat offering and a drink offering unto the LORD your God? (Joel 2, 13-14). We all need to return wholeheartedly to the Lord, in order to have always the confidence that He will help us. Perhaps we don't have the spirit of confession, perhaps the cold and distant spirit grasps us, the indifference and spiritual coldness wraps us, but for all of these there is only one remedy, namely, the return with faith and repentance towards God, confessing our sins and with the desire to be free from all filthiness of sin, wanting to live every day after our Lord's holy counsels. Confessing our sins should be a spiritual priority for us. Through what is really man falling? Not through his iniquity? We should always ask ourselves this question: Did we confessed all our sins? Do we have the assurance that God has forgave us, cleansed and healed us from the sin? Oh! God help us to confess our sins, to repent of them and give us your forgiveness. Divinity wants to restore the link with man forever, for which awaits the return of the human being, according to the Sacred Scripture words: "O Israel, return unto the LORD thy God; for thou hast fallen by thine iniquity. Take with you words, and turn to the LORD: say 
unto him, Take away all iniquity, and receive us graciously: so will we render the calves of our lips."30

\section{The Return of Man to God Must Not Be Delayed}

"Let us therefore fear, lest, a promise being left us of entering into his rest, any of you should seem to come short of it."31 The whole sky, full of celestial blessings, is ready to overfill in every human soul, as a reward for all those who will return to God and who will ask with faith the help of our Savior, Jesus Christ. He is ready and is willing to give us the Kingdom of Heaven. Our Lord Jesus Christ said: "Let not your heart be troubled: ye believe in God, believe also in me. In my Father's house are many mansions: if it were not so, I would have told you. I go to prepare a place for you. And if I go and prepare a place for you, I will come again, and receive you unto myself; that where I am, there ye may be also. ${ }^{32}$ Life is full of problems and challenges. When we look at God, our troubles become opportunities in which he can intervene. And for the future, as Christians, we cannot confide in our own strength, but only in His strength. The relationship with God is a source of energy for the whole Christian experience and prepares us for eternity. ${ }^{33}$

For all the help that Our Good Heavenly Father has given to us so far, for the entire ensure of His support, for our future, we can be grateful, because our help comes only from God, and for that HE deserves to thank Him always, saying together with all the holy beings: "And I beheld, and I heard the voice of many angels round about the throne and the beasts and the elders: and the number of them was ten thousand times ten thousand, and thousands of thousands; Saying with a loud voice, Worthy is the Lamb that was slain to receive power, and riches, and wisdom, and strength, and honor, and glory, and blessing. And every creature which is in heaven, and on the earth, and under the earth, and such as are in the sea, and all that are in them, heard I saying, Blessing, and honor, and glory, and power, be unto him that sitteth upon the throne, and unto the Lamb for ever and ever." 34 


\section{The Biggest Event of the Future: The Coming of Jesus for the Second Time}

The thought of waiting for the consolation of Lord, for His kingdom, the expectation of our salvation offered through the Sacrifice on the Cross of our precious Savior Jesus Christ, serve to strengthen further our Christian convictions and to make more powerful the longing that pulses in every one which is expecting through his faith the happiness and the eternal salvation. The Holly Scripture brings before us the faithful Simeon, who, even if advanced in years, and even if this years brought with them physical and often spiritual fatigue, old faithful Simeon could have been turned into a solitary man somewhere in a house in Jerusalem, where to enjoy serenity and calm. Instead, Simeon never missed to attend that time and sharing their hopes and expectations, namely those concerning the coming of the Messiah. Old Simeon was waiting for the consolation of Israel and for the wonderful redemption of the Lord. "And, behold, there was a man in Jerusalem, whose name was Simeon; and the same man was just and devout, waiting for the consolation of Israel: and the Holy Ghost was upon him. And it was revealed unto him by the Holy Ghost, that he should not see death, before he had seen the Lord's Christ."35 In all his prayers, he sent the sighing of his heart and his desire as the Gracious Heavenly Father, the Almighty God, not to call him to rest until he sees the Saviour, the promised Redeemer the Messiah awaited and desired. Simeon's soul desire was heard and the Holy Spirit gave him notice that he would not sleep the sleep of death, until he will see, the promised Redeemer, Jesus Christ. "And it was revealed unto him by the Holy Ghost, that he should not see death, before he had seen the Lord's Christ." ${ }^{36}$

Certainly the faithful old Simeon had all kinds of questions in his mind about where, how the Redeemer will come. But old Simeon also knew that if he would be ubiquitous from the Temple in Jerusalem, if he would keep uninterrupted his connection with the Holy Spirit who warned him, through prayer and mysterious meditation, then he should not be pressed by any care, regarding how Israel's consolation, the Redeemer of the world will come. We 
do not know today how long Simeon waited, how many years passed before he saw the Messiah. We know only the fact that coming one day to the temple, inspired and driven by the Holy Spirit, had the happy opportunity to see the young child Jesus Christ. The Holly Gospel tells us that the old man Simeon took the child in his arms and blessed God: „And he came by the Spirit into the temple: and when the parents brought in the child Jesus, to do for him after the custom of the law, then took he him up in his arms, and blessed God, and said, Lord, now lettest thou thy servant depart in peace, according to thy word: For mine eyes have seen thy salvation, which thou hast prepared before the face of all people; A light to lighten the Gentiles, and the glory of thy people Israel." 37

With this sacred occasion, Simeon, after he blessed Joseph and Mary uttered some prophetic words: „And Joseph and his mother marveled at those things which were spoken of him. And Simeon blessed them, and said unto Mary his mother, Behold, this child is set for the fall and rising again of many in Israel; and for a sign which shall be spoken against; (Yea, a sword shall pierce through thy own soul also,) that the thoughts of many hearts may be revealed." ${ }^{8}$ Simeon left the temple happy, ready to die at any time, because his eyes have seen the salvation, have seen the Lord.

Simeon, the old faithful from the temple, represents all those believers, which compared with the entire world, are a minority, but which are waiting with faith and want above all things to see Jesus the Savior, the One who called them to salvation and eternal happiness. Simeon's spirit of faith lives not only in elderly belivers but also in young people. This spirit lives in every heart that desires and expects the day of salvation, the Day of our Lord Jesus Christ, the great day of the final rewards. These believers, like old man Simeon, are waiting to see the Lord, keeping alive and uninterrupted their connection with heaven. And the Holy Spirit notify them about all the events that will come into the world. This category of faithful people are waiting day by day the coming of our Lord Jesus Christ, expecting year after year the fulfillment of the Holy Scripture words. They are sincere believers and glorifiers of God. This kind of believers, never miss the religious ceremonies from the Temple (the Church) and from every sacred ceremony they learn something, they find 
comfort in distress, they find the power to strengthen their faith, ensuring themselves that Jesus Christ will return again with glory and honor: "Looking for that blessed hope, and the glorious appearing of the great God and our Saviour Jesus Christ; Who gave himself for us, that he might redeem us from all iniquity, and purify unto himself a peculiar people, zealous of good works. ${ }^{\text {39 }}$

In this way things happened with old Simeon in Jerusalem, at the first comwill happen with those who live happily waiting for the glorious appearing of the Almighty God of our Savior Jesus Christ. Are we waiting as Simeon? Are we always driven in our activities by the Holly Spirit? Are we customary from the holy church services? When we participate in the House of God, at the sacred ceremonies, can we draw from these ceremonies the fact that our Lord is coming as He promised: "Let not your heart be troubled: ye believe in God, believe also in me. In my Father's house are many mansions: if it were not so, I would have told you. I go to prepare a place for you. And if I go and prepare a place for you, I will come again, and receive you unto myself; that where I am, there ye may be also." 40 Some of the people expect their selfish plans to be fulfilled, others expect something bad to happen to their enemies, but the old man Simeon is waiting for the consolation of Israel. The consolation is that attribute, that encouragement, they all need, but wich it possesses only by some people. Our Lord teaches us to weep with those who weep: "Comfort ye, comfort ye my people, saith your God. Speak ye comfortably to Jerusalem, and cry unto her, that her warfare is accomplished, that her iniquity is pardoned: for she hath received of the LORD'S hand double for all her sins." ${ }^{41}$ Simeon was a believer waiting for the Messiah, and we as Christians in this latter days, we are those expecting the second coming of our Lord Jesus Christ.

\section{What Does it Mean for Today's Christians} the Future Awaiting of our Lord Jesus Christ?

Adam and Eve were waiting for the promised Redeemer: "And Adam knew Eve his wife; and she conceived, and bare Cain, and said, I have gotten a man from the LORD."42 Our ancestors Adam and Eve, believed their son Cain, was to be their Saviour and the Saviour of the world, but it turned out that he became the murderer of his brother 
Abel, being upset that the sacrifice of his brother was better received than his sacrifice. Cain should have learnt that his brother sacrifice symbolized the Sacrifice on the Cross of our Lord Jesus Christ. Cain didn't had to be angry, to be envious, but to learn himself and do as his brother.The Day of the Lord will be a great and a wonderful day, and will be enjoyed by all the right believers, but for those who live carelessly, unprepareing themselves for the Day of the Lord, this day will be one of mourning, of oppression, of sadness and darkness. It will not be a holy lighted Day of Lord.

Enven today there are Christians who believe that time passes, the prophecies about the coming of Christ remaining unfulfilled and nothing special happening in this respect: "Son of man, what is that proverb that ye have in the land of Israel, saying, The days are prolonged, and every vision failed? Tell them therefore, Thus said the Lord GOD; I will make this proverb to cease, and they shall no more use it as a proverb in Israel; but say unto them, The days are at hand, and the effect of every vision. For there shall be no more any vain vision nor flattering divination within the house of Israel. For I am the LORD: I will speak, and the word that I shall speak shall come to pass; it shall be no more prolonged: for in your days, $O$ rebellious house, will I say the word, and will perform it, said the Lord GOD." ${ }^{\prime 3}$ This is a great delusion to believe that time passes without any change and that the word of God will not be fulfilled.

Even today there are some Christians who are asking where is the promise of His coming, because from the time their parents are asleep ultil our days all things remained as they were: „And saying, Where is the promise of his coming? for since the fathers fell asleep, all things continue as they were from the beginning of the creation." 44 Our good Lord do not delay the coming of the blessed Son, but has a sacred purpose, namely saving the people. The Lord is not interested in the destruction of the world, but he is interested to save it. The Apostle Peter said in his time, that: „The Lord is not slack concerning his promise, as some men count slackness; but is longsuffering to us-ward, not willing that any should perish, but that all should come to repentance." 45 "And account that the longsuffering of our Lord is salvation; even as our beloved brother Paul also according to the wisdom given unto him hath written unto you." ${ }^{\prime 6}$ 


\section{The Waiting State of the World}

\section{in Simeon's Time or Before That Time}

The people in Simeon's time were awaiting the Messiah: "And as the people were in expectation, and all men mused in their hearts of John, whether he were the Christ, or not." ${ }^{\prime 7}$ Prophet Ana toghether with other devouted men were waiting for redemption: „And she coming in that instant gave thanks likewise unto the Lord, and spoke of him to all them that looked for redemption in Jerusalem." ${ }^{48}$ As others, Joseph of Arimathea, was also one of those waiting for the Kingdom of God: "Joseph of Arimathaea, an honorable counselor, which also waited for the kingdom of God, came, and went in boldly unto Pilate, and craved the body of Jesus." ${ }^{\prime 49}$ About Joseph of Arimathea and Nicodemus it was thought they were the richest people of those places and that they could support even the city of Jerusalem for quite a while. For a while these men sat in the shade, but after the death on the Cross of Jesus Christ, they showed faith and respect for His teachings and proved to others that they were disciples of the Lord, waiting for the kingdom of God. Also our forefather Abraham was one of those expecting the Kingdom of God: „By faith Abraham, when he was called to go out into a place which he should after receive for an inheritance, obeyed; and he went out, not knowing whither he went. By faith he sojourned in the land of promise, as in a strange country, dwelling in tabernacles with Isaac and Jacob, the heirs with him of the same promise: For he looked for a city which hath foundations, whose builder and maker is God. "50

\section{Awaiting and Preparing for the Return of Jesus Christ}

The word of God, presented in the Holy Scripture, tells us: „For our conversation is in heaven; from whence also we look for the Savior, the Lord Jesus Christ." "Looking for that blessed hope, and the glorious appearing of the great God and our Savior Jesus Christ"52

„Seeing then that all these things shall be dissolved, what manner of persons oughtye to be in all holy conversation and godliness, Looking for and hasting unto the coming of the day of God, wherein the heavens being on fire shall be dissolved, and the elements shall melt with fervent heat? Nevertheless we, according to his promise, look for new 
heavens and a new earth, wherein dwells righteousness. Wherefore, beloved, seeing thatye look for such things, be diligent that ye may be found of him in peace, without spot, and blameless." ${ }^{53}$ Like the right believers of old times, Simeon, Anna, Joseph of Arimathea, Abraham and many others over time, the people of our age, awaits even today, at the twilight of earth's history, the salvation and consolation of the eternal life promised by the invaluable Sacrifice offering from the Cross of Calvary.

The Archimandrite Placide Deseille said that the Christian is a man which is awaiting. If we want to rediscover Christianity alive, which is for us an endless source of joy and spiritual impetus, we must reinstate in the center of our Christian life, the eager expectation and the certitude of the glory coming of our Lord, desire and conviction which animated the early Christians. ${ }^{54}$

St. Gregory of Nyssa said that we will be seeking, as it will be possible, the clean colors of virtues, mixed in a crafted blend, to take likeness of the beauty that we had before, in order to be a wise of the Image, managing to fulfill in our lives, through imitation in facts, the beauty of the model before us, as Apostle Paul did, becoming an image of Christ, through a virtuous life. ${ }^{55}$

The Church not only teaches about what God has done to save human being, but also about what He is preparing for those who believe in Him. In this regard, the Christian life is placed under the sign of hope and resurrection, and under the sign of preparedness for the celestial life. ${ }^{56}$ Because of this the true believers are not afraid of the last moments of life and stay peacefully in front of any threats, being convinced that those are nothing else than manifestation of evil. $^{57}$

\section{Conclusions}

It is possible that the future perspectives, for some or for others, not to look always in the most pleasant or desirable way, and you may face difficulties, losses of various natures, however, deterrence should not comprise anyone. A true Christian believes and learns that in such situations worries must to be thrown on The One who 
has and who can do everything. It is true that the divinity promises relief, but not without human collaboration, but confident in the Good Lord-Our help, we must do everything that stands in our power, then the future can be viewed with confidence and peace of mind. ${ }^{58}$

We, as people, we can see future ${ }^{59}$ only through faith, and we can take God's promises as a guarantee of increasing our intellectual power, uniting our human faculties with the divine ones, bringing the full power of our being directly connected to the source of light. Let us rejoice that everything that has perplexed us in God's providence works will be clear then, and things that were hard to understand now will then be explained; and where our limited mind and understanding saw only confusion and thwarted plans, we will get to see the most perfect and beautiful harmony. ${ }^{60}$ Apostle Paul spoke about our partial limited knowledge: "For now we see through a glass, darkly; but then face to face: now I know in part; but then shall I know even as also I am known." ${ }^{1}$

\section{NOTES}

${ }^{1}$ The material presented in a sparing form within Ioan-Gheorghe Rotaru, “De unde-mi va veni mie ajutorul ?”, Argeşul ortodox, 555 XI (2012), 5; Idem, "Aşteaptă şi tu mângâierea Domnului !”, Argeşul ortodox, 558 XI (2012), 5.

${ }^{2}$ Cf. Benone Burtescu, Caci noi n-avem o cetate statatoare, http://www. resursebiblice.ro/2012/caci-noi-n-avem-o-cetate-statatoare/ (Last accesed 17.04.2016)

${ }^{3}$ Ellen G.White, Calea către Hristos (București: Institut de Arte Grafice și Editură "Graiul Literar"), 107

${ }^{4}$ Nicolae Stoleru, Spiritualitatea ortodoxă și slujirea creștină, teză de doctorat (București: Editura Institutului Biblic și de Misiune al Bisericii Ortodoxe Române, 1991), Ortodoxia, 2, XLII (1990), 30.

${ }^{5}$ Ellen G.White, Patriarhi și profe? $i$ (București: Editura Viață și Sănătate, 2011), 32-40.

${ }^{6}$ The Holy Bible (King James Version, Cambridge: Cambridge University Press), The Old Testament, Genesis 2, 18

${ }^{7}$ Malachi, 4: 5-6.

${ }^{8}$ Stelian Negoshanu, Vino, Doamne Isuse! (București: Editura Viață și Sănătate, 1999), 89.

${ }^{9}$ Ellen G.White, Divina vindecare, ed. a 3-a (București: Editura Viață și Sănătate, 2010), 261. 
${ }^{10}$ Ellen G.White, The Adventist Home. Chapter 78-The Family a Missionary Center http://text.egwwritings.org/publication.php?pubtype=Boo k\&bookCode=AH\&lang=en\&pagenumber $=484 \& \mathrm{~m}=1$ accessed April 172016.

${ }^{11}$ Exodus $2: 23-25$

${ }^{12}$ Psalms 35: 25.

13 Sf. Chiril al Alexandriei, Scrieri. Partea Întâia. Închinarea și slujirea în Duh și în Adevăr, trad. Dumitru Stăniloae, (București: Editura Institutului Biblic și de Misiune al Bisericii Ortodoxe Române, 1991), 290-295.

${ }^{14}$ Exodus 25: 16-22.

${ }^{15}$ Ellen G.White, Patriarhi și profe 1 i (București: Editura Viață și Sănătate, 2011), 359.

${ }^{16}$ Tache Sterea, "Dumnezeu, Omul și Creația în teologia ortodoxă și în preocupăprile ecumenismului contemporan," Ortodoxia, 1-2, XLIX (1998), 81.

${ }^{17}$ PF. Teoctist, Patriarhul Bisericii Ortodoxe Române, „Precuvântare”, Studii Teologice, I (2005), 8.

${ }^{18}$ Sf. Chiril al Alexandriei, Scrieri. Partea Întâia. Închinarea și slujirea în Duh și în Adevăr, trad. Dumitru Stăniloae, (București: Editura Institutului Biblic și de Misiune al Bisericii Ortodoxe Române, 1991), 570.

${ }^{19}$ Constantin C. Pavel, „Eroismul în lumina moralei creștine (II)”, Studii Teologice, 1-2, XLV (1993), 30.

${ }^{20}$ Psalms 46: 1-8.

${ }^{21}$ Jeremiah 15: 19-21.

${ }^{22}$ Psalms 124: 8.

${ }^{23}$ Psalms 28: 7-8.

${ }^{24}$ Psalms 37: 23-25.

${ }^{25}$ Sf. Chiril al Alexandriei, Scrieri. Partea Întâia. Închinarea și slujirea în Duh și în Adevăr, trad. Dumitru Stăniloae, (București: Editura Institutului Biblic și de Misiune al Bisericii Ortodoxe Române, 1991), 271.

${ }^{26}$ Ellen G.White, Calea către Hristos (București: Institut de Arte Grafice și Editură „Graiul Literar”), 72-73.

${ }^{27}$ Lamentations 5: 15-22.

${ }^{28}$ Constantin C. Pavel, „Eroismul în lumina moralei creștine (II)”, Studii Teologice, 1-2, XLV (1993), 12

${ }^{29}$ Ibidem, 30.

${ }^{30}$ Hosea 14: 1-2.

${ }^{31}$ Hebrews 4: 1.

${ }^{32}$ John 14: 1-3.

${ }^{33}$ Mark Finley, Casa zidită pe Stâncă (București: Editura Viață și Sănătate, 2011), 242, 323.

${ }^{34}$ Revelation 5: 11-13.

${ }^{35}$ Luke 2: 25-26.

${ }^{36}$ Luke 2: 26.

${ }^{37}$ Luke 2: 27-32.

${ }^{38}$ Luke, 2: 33-35. 
${ }^{39}$ Titus 2: 13-14

${ }^{40}$ John 14: 1-3.

${ }^{41}$ Isaiah 41: 1-2.

${ }^{42}$ Genesis 4: 1.

${ }^{43}$ Ezekiel 12: 22-25.

${ }^{4} 2$ Peter 3: 4.

452 Peter 3: 9.

462 Peter 3: 15.

${ }^{47}$ Luke 3: 15.

${ }^{48}$ Luke 2: 38.

${ }^{49}$ Mark 15: 43

${ }^{50}$ Hebrews 11: 8-10.

${ }^{51}$ Philippians 3:20

${ }^{52}$ Titus 2: 13

${ }^{53} 2$ Peter 3: 11-14

${ }^{54}$ Arhim. Placide Deseille, „Moartea a fost biruită”, Ortodoxia, 1-2, XLIX (1998), 97.

${ }^{55}$ Sfântul Grigorie de Nyssa, Scrieri exegetice, dogmatico-polemice și morale, trad.T.Bodogae (București: Editura Institutului Biblic și de Misiune al Bisericii Ortodoxe Române, 1998), 468.

${ }^{56}$ Ion Bria, „Învățătura ortodoxă despre viața viitoare”, Ortodoxia, 1, XXXVI (1984), 27.

${ }^{57}$ Petru I David, „A II-a venire a Domnului (Parusia)”, Ortodoxia, 1, XXXVI (1984), 114.

${ }^{58}$ Ellen G.White, Calea către Hristos (București: Institut de Arte Grafice și Editură "Literar"),107.

${ }^{59}$ Ioan Mircea, „A doua venire a Domnului (Parusia) ”, Indrumări misionare, (București: Editura Institutului Biblic și de Misiune al Bisericii Ortodoxe Române, 1986), 909-935.

${ }^{60}$ Ellen G.White, Calea către Hristos (București: Institut de Arte Grafice și Editură „Graiul Literar”), 98-99.

611 Corinthians 13: 12. 